\title{
CHANGES IN THE ORGANIZATIONAL STRUCTURE OF LOGISTICS ENTERPRISES IN THE CONDITIONS OF THE MODERN CRISIS
}

\author{
Ljiljana Stošić Mihajlović1, Marijana Jevtić Radulović², Svetlana Trajković3, \\ ${ }^{1,3}$ Academy of Applied Technical and Perschool Studies, Niš - Department in Vranje, Serbia \\ 2 "Dositej Obradović" School, Vranje, Serbia \\ stosicmihajlovicljiljana@gmail.com, cecasvtr@yahoo.com, majajevticradulovic@gmail.com
}

Original Scientific Paper
10.5937/jouproman8-28295

\begin{abstract}
In modern business conditions burdened by the crisis caused by the COVID-19 virus, all areas of life and work of modern civilization are deeply affected. All companies in modern economies have had a negative impact on the crisis. The logistics services sector is particularly affected. Companies that provide logistics services are now faced with a special requirement in terms of responding quickly to the challenges posed by quality logistics operations during a pandemic. For these reasons, as in other industries, companies in the logistics sector must adapt quickly to the challenges. The best way to adapt is to change the organizational structure of logistics companies, in accordance with the challenges imposed by the circumstances in the environment. This paper will discuss the necessary changes in the organizational structure of logistics companies, in order for these companies to continue or improve their business system, in accordance with the changes and challenges that come from the external environment.
\end{abstract}

Keywords: organizational structure, logistics, transport logistics, change management, crisis management, markets, COVID-19

\section{Introduction}

In essence, the organizational structure is a way of decomposing the basic task of the company into its constituent units. What the specific organizational structure will be, largely depends on the activity in which the company is engaged, but also on external opportunities and circumstances, ie on the environment, both internal and external, in which the company operates. „In today's competitive world, there is always a need for improvement regarding the performance of businesses."1

Inmodern conditions, as never before in the modern history of civilization, people have encountered a pandemic, ie a disease that affects the whole world and for which there is no perfect cure at the moment. „The neoliberal model of economic development implemented by the most developed countries of the West in the recent years has caused great financial world crisis; it also led to a slowdown in the world economic growth as well as huge social inequality in the world." ${ }^{2}$ A coronary virus pandemic called SARS COV-19 has so far taken more than $1 / 2$ million of the world's population and affected all the world's economies. Namely, the most powerful and economically most developed countries, such as the USA and Great Britain, are currently on their knees, and workers in all countries of the world are losing their jobs en masse, due to the economic crisis caused by this new virus.

\footnotetext{
${ }^{1}$ Alhasheedi, A. A. A., Bin, B. B., \& Mustafa, A. M. [2020]. The effect of transformational leadership behavior on organizational performance in gold industry of Saudi Arabia. Journal of Process Management. New Technologies , 8(3), 6281.
2 Aničić, J., \& Aničić, D. [2019]. Which model of economic development is the best for Serbia. Journal of Process Management. New Technologies, 7(4), 46-56.


Everyone suffers damage, especially companies that are dependent on the free flow of people, goods and capital. In that sense, logistics companies have not been spared either. The only response to the crisis is a rapid transformation and adjustment of the organizational structure in accordance with the changing conditions of entering the market. Every organization in the logistics sector is trying to cope with the changes in the best way, sometimes successfully and sometimes less successfully, because there is no single answer to the challenges from the environment, or can there be. In that sense, every logistics organization strives to continue or improve its business primarily through internal changes in the organizational structure.

\section{Organizational changes}

Organizational changes are carried out in order to survive and develop the organization, but also preventively to prevent the organization from coming into an unfavorable situation. In that sense, corrective changes are made, when an unfavorable situation for the organization already occurs. When implementing changes in an unstable environment caused by a pandemic, it is necessary to combine knowledge in the field of medicine with knowledge in the field of economics, such as economic systems, the way organizations work, the system of economic legislation, human resources management, policies such as political organization and sociology - especially in the part that includes basic social norms, stratification of society, needs and motivation of the population. Organizational management research shows that crisis situations affect changes in management. We still have companies that are managed in an inherited way based on the expectation that the crisis situation will end, or state intervention and economic assistance is expected in the conditions of a pandemic in the payment of salaries, as the basic motive for doing business. The management of organizational changes in such companies is also outdated, which means that individual initiative is not encouraged, the separation of the management structure from the employees is expressed. Employers strive for higher productivity and higher quality of business even in conditions of unstable business, while employees want good wages and satisfaction with the overall business conditions, which leads to certain resistance from employees. In the conditions of the health crisis, some organizations managed to build an organizational structure that promotes different values of the organization and raises the competitiveness of the organization in the domestic and foreign markets. New ways of doing business have increased, in most cases, the productivity and economy of doing business, but not the emotional satisfaction of employees in terms of caring for their own health. On the other hand, it has been shown that raising the quality system and improving the health care of employees at a random place does not automatically trigger organizational changes. Some research has already shown that the introduction of mandatory health standards for business in a pandemic is not a sufficient driver of change in the organization. One of the explanations for this phenomenon is that occupational safety measures are introduced only formally, without a real impact on the functioning of the organization.

\section{Management of changes in the organizational structure of logistics enterprises}

In the literature, there are different interpretations of the very concept of logistics. In military terminology, this term has been used since Napoleon's time to describe the unified activities of transportation, supply and accommodation of military units. 
Today's understanding of logistics describes it as a system of activities that enable the design, design, direction, guidance and regulation of human flow of goods (materials, products), energy, fluids and information within the system and between systems. In essence, logistics deals with the analysis of activities in the company, through the prism of process actions, following the flow of raw materials at the entrance to the company input logistics; flows of raw materials and semi-finished products through the company - internal logistics; and flows of final products and goods - output logistics. Increasing market flexibility is taking up, becoming an increasingly important activity of logistics, in defining the strategic goals of the organization. In modern conditions, great attention is paid to the motives, needs and desires of customers, as well as quality as the basic factors of market success, which conditions the orientation of production to function in accordance with market demand and customer requirements. The feeling for the wishes and needs of customers leads to an increase in variants of the same products, as well as expanding the range by introducing new products, which results in increased production flexibility and delivery system to markets in a way and at a time convenient to customers. There is a connection between the organizational and technological aspect that must be taken into account when realizing this concept. By methodically building operational process logistics chains, this connection can be determined and the desired flow of order realization can be achieved. Within the logistics chains with pronounced basic business functions "order - produce - sell", logistics tasks are performed at the dispositive level (eg increase the security of meeting needs, achieve exact "Make-or-Buy" decisionmaking, determine the exact moments of identifying and meeting needs, ensure security of supply with timely deliveries with minimal procurement costs, as well as simultaneous planning of capacities and deadlines to enable fast delivery with invoicing). In order for production to take place in accordance with market requirements, a strong link must be achieved between all segments of the business system, primarily by creating logistics chains in the relationship sales (marketing) - procurement - production, in order to eliminate factors that create stocks and extend production time product. This requires an internal or inter-operational distribution of tasks and the detailed design of new, logistically based material and information flows. By quickly informing about the needs of end customers, there is a "suction" effect that accelerates material flows. "On-demand production" that applies to all participants in the logistics chain also enables a reduction in inventories in preparation, thanks to production segmentation, the concept of preparation and the accumulation of experience." ${ }^{3}$

A well-designed organization of logistics companies presupposes changes in the organization in order to approach the requirements of the market, such as orientation to market goals and the existence of several stages of the logistics chain in the organizational unit.

Changing the organization of logistics means the orientation of the overall activity of the company according to market demands. The most important marketing goal is to meet customer requirements in terms of product quality, delivery times and good information, and a pre-known customer order means production for a known customer by combining all stages from start to finish of product development.

\footnotetext{
${ }^{3}$ Midžić, A. [2014]. Logistika,, Bihać, prema: Ballou R.H., Business Logistics Management, Prentice-hall international, Inc., Upper Saddle River, 5-20.
} 
Logistic management and adjustment of the organizational structure achieves the goal of market competitiveness by using management tools, which are:

1) integration and optimization - means the reduction or elimination of unnecessary functions and systems such as finishing and inventory;

2) continuous improvement - implies the development of internal systems that encourage continuous improvement of processes and procedures;

3) respecting the needs of the customer means meeting the customer's wishes and reducing his costs of ordering and using the product, which is realized by meeting 7 basic requirements:

- the right product,

- in the right place,

- at the right time,

- in the right amount,

- the right quality

- for the right customer

- at real cost.

\section{Logistics organization and the importance of organization in logistics}

"What about logistics and supply chains in the market? Is there an impact of the COVID-19 virus on logisticians' obligations when securing market requirements in accordance with international business standards? Most entities have focused their attention on protecting employees, perceiving and managing risks that are threatening to business, and managing supply chain downtime due to efforts to curb the spread of virus coronas." 4

${ }^{4}$ Stošić-Mihajlović, L., \& Trajković, S. [2020]. The importance of logistics and supply chains for pandemia conditions. Journal of Process Management. New Technologies , 8(2), 53-59.
For efficient and effective management of the business logistics function, an appropriate organizational structure is necessary. When organizing logistics activities, the basic problem of logistics organization is the deployment of persons responsible for logistics activities, in a way that encourages coordination between them in order to realize the overall task of the company. Work schedules provide for the supply and distribution of goods and services, improving the balance between costs. In this regard, the need for the organizational structure of logistics organizations is evident. Namely, the organizational structure is needed for the following reasons:

1) Conflict resolution - In a traditional organization, all activities in the company are grouped into three basic functions: finance, production and marketing. From the point of view of logistics, this means that logistics activities are divided between these three functions so that transport falls under production, goods are divided between all three functions, and procurement is classified as marketing or finance. This way of organization is not optimal, because it leads to conflicting partial interests - marketing tends to increase revenue, production seeks to produce at the lowest cost, while finance tends to reduce capital costs by increasing return on investment.

2) Management of the organization - The optimal organizational structure of logistics activities determines the necessary directions of authority and responsibility, in order to ensure the transport of goods according to plan and in accordance with the defined task. The balance between customer service and costs is important, so that the transport of products must be managed by the logistics manager, ie. to supervise the combined activities of procurement, transport and storage and, in order to achieve maximum efficiency, to balance between these activities. 
It is certain that logistical issues are not equally important in all companies. In those business systems where little is invested in logistics and where customer service is not taken into account, logistics will not receive much organizational attention. However, in at least $1 / 4$ companies (food, chemical industry, etc.), logistics costs are over $25 \%$ of sales, so that logistics gained its organizational form and importance. The need for a specific type of logistics organization depends on where and how logistics costs occur and where the greatest needs for services are. The extractive industry produces basic raw materials for the processing industry, and procurement and transport are the basic logistics activities related to stocks. The main task is transport control, which includes the choice of mode of transport, the choice of a specific transport route and the utilization of the capacity of the equipment of means of transport. That is why companies in this industry have organizationally prominent material management departments. The service industry is mainly engaged in logistics activities related to stocks. Businesses convert actual inventory into service offerings. Examples of such organizations are hospitals, insurance and transportation companies. Namely, various goods are purchased from geographically and transport-distant suppliers, and are used in creating services for the end consumer. The basic logistics activities are procurement and goods management, while transport is not given more importance, because most of it is procured at a pre-agreed price. In these business systems, the logistics organization focuses on materials management and covering physical distribution activities. Marketingoriented companies are characterized by the purchase of goods for the purpose of resale and earnings based on the difference in price. Typical representatives are distributors and wholesalers and retailers. These companies do nothing to change the shape, composition or quality of products, their main job is sales and logistics activities. It is characteristic of these companies to buy (mostly a large quantity) goods from different, geographically dispersed suppliers. Goods are resold in numerous combinations, in small quantities, usually in a geographically limited area. The characteristic activities of these business systems are procurement, export transport, goods management, warehousing, order processing and delivery. The organization of logistics management in these companies is of great importance and includes material management and physical distribution. During the supply of end customers and the broadest strata of the population during the pandemic with the COVID-19 virus, the emphasis is on the strong organization of physical distribution.

Attitudes about the organizational development of opinions about what is good logistics management have changed over time. However, modern business logistics is characterized by insistence on the phase of organizational structuring of business logistics activities, based on the full integration of logistics operations and tasks, including physical procurement and physical distribution. The reason for the great popularity of the integration of logistics activities and organizational structure is the growing need for compliance with delivery deadlines, quick response and reduced waiting time for delivery, which requires precise coordination of all tasks in the company.

The assets of logistics and transport logistics companies, which include rolling stock, warehouses, material handling equipment, used for procurement and physical distribution, require coordination in order to implement the business process and supply chain management. Managing an organization that deals with the logistics function opens up new challenges, but also opportunities for efficiency that have not yet been used by the organizational structure. 
Organizational choice means that when the need for some form of organizational structure is identified, the company can opt for:

(a) informal,

(b) semi-formal) or

(c) the formal form of the organizational structure.

None of the mentioned organizational choices is dominant in relation to the others, but for a specific company in the logistics sector it is most often the result of the actions of the development forces that function in it. The logistical organizational form is envied by internal factors, such as: company assets, tradition of the organization, the level of importance attached to logistics activities. Informal organizational form - the main task of the logistics organization is the coordination between logistics activities, their planning and control. If there is support in the company, coordination of logistics activities can be achieved in an informal way, which does not require a change in the existing organizational structure, but is based on the compulsion to achieve coordination, between activities and between persons responsible for them. In companies that have opted for this domain of responsibility, the key logistics activities are: transport, goods control and the procurement process. The highest level of management easily oversees the decisions in the organization and has mechanisms by which it can encourage, support coordination and cooperation among the activities for which its managers are directly responsible.

Semi-formal organizational form - is often called the matrix form of organization and starts from the fact that logistical planning and action usually goes beyond the framework of various functions within the organizational structure of the company. Logisticians must coordinate projects that involve logistics and that cover several functional areas. It is adapted to the management of the logistics system. In this organization, the logistics manager is responsible for the entire logistics system. The traditional organizational structure remains intact, but the logistics manager shares electoral authority and responsibility with managers of other business functions. Although the matrix organization of logistics companies is an important form of organization, its main drawback is that lines of government and responsibilities can become blurred and thus can lead to difficult problems in mutual coordination. Its main advantage is that it represents a reasonable compromise between an informal and a highly structured organizational form.

The choice of a specific organizational structure depends on the business policy that the company implements. The organization follows three joint strategies: processes, market, and information.

The process strategy aims to achieve maximum efficiency in the production of products from raw materials, through processing to the final product. The organization will focus on activities that lead to increasing the value of products the processes of supply and procurement, planning and monitoring of production, transport and inventory will be treated together and managed jointly.

The market strategy is used by companies that have a strong orientation towards providing services to customers. Sales and logistical coordination are also being forced. The organizational structure will not integrate logistics activities that are closely related to the process strategy, but only those activities that relate to customer service. The organizational structure is built through business units in order to better provide services and respond quickly to customer requests. 
The information strategy is implemented by companies that have a smaller network of sellers and distribution organizations with larger stocks. The primary goal of the information strategy is to consolidate logistics activities in the network, using information as a key element of good governance.

In practice, there are no cases when one company has an organization that follows only one of the mentioned strategies, conversely, the same company has a mixture of strategies, which in practice can happen that for essentially similar companies there are different organizational forms. Differences usually occur due to unequal levels of organizational development.

\section{Changes in logistics organizations}

"Overcoming physical barriers between buyers and sellers, when the delivery of the goods in question or of passengers it comes to passenger traffic, is the main task of logistics, practices and skills. When it concerned modern trends clearly we can say that the future has already begun." 5

Managing change in organizations that are predominantly engaged in logistics processes requires a combination of the achievements of theory and operational burst. Change management theory encompasses several different and mutually compatible approaches, the most well-known approaches being: organizational development; organizational transformation; institutional theory of change; decay; reduction; turn of the organization; organization life cycle; changes in conditions of uncertainty; population ecology theory; total quality management (TQM); business process

\footnotetext{
${ }^{5}$ Stošić-Mihajlović, L., \& Trajković, S. [2017]. Logistics support as efficient business and transport. Journal of Process Management. New Technologies, 5(1), 30-36.
}

reengineering; organizational learning and knowledge management.

Change management is aimed at solving the following problems, these are: organizational development, organizational transformations; organizational adaptations; process approach to quality and business processes; organizational learning and knowledge management.

The environment is one of the most important factors influencing changes in organizations. The turbulence in the environment is increasing. The company is forced to adapt to the factors and requirements of the environment, and the ability to change and flexibility are the most important features of a modern company. The flexibility of the organization can be:

- functional (ability to transfer employees from one job to another);

- numerical (enables successful performance of jobs with a smaller number of full-time employees);

- financial (ability to quickly adjust costs and earnings to market conditions).

The process of change itself represents the transition from the existing to some future state of the organization (Figure 1).

The transition situation is the most critical period because the organization is "in transition". It is necessary to objectively and exactly determine the organizational parameters before and after the changes. It is important to establish an objective picture of the organization that is changing. It must not be the result of the desires or emotions of individuals or groups. The success of change cannot be easily and quickly determined and measured. A change is considered successful if the following conditions are met:

- the transition of the organization from the existing to the desired state has been achieved; 
- the new situation gives results that are measurable;

- the transition was realized without major consequences and costs;
- the new situation does not cause significant consequences for the company's employees.

Figure 1. The process of organizational change

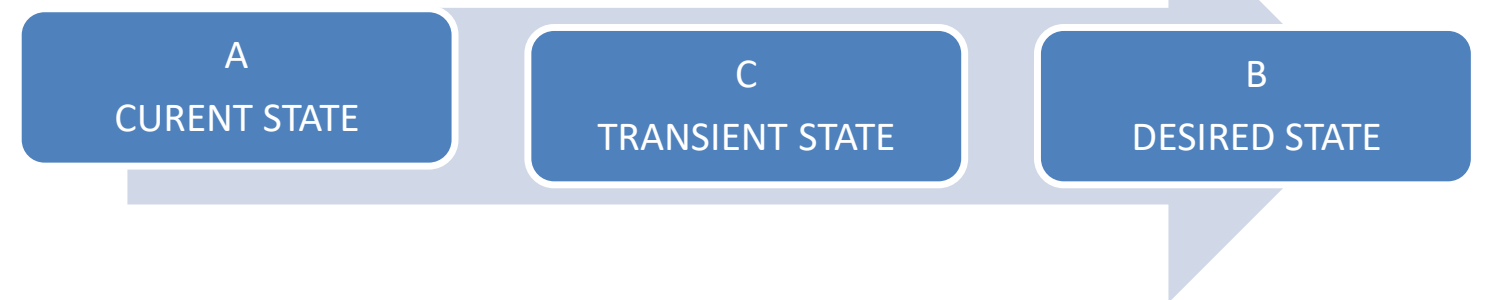

For successful implementation of change, the approach as well as the way of implementing change is important. The approach should be appropriate to the existing conditions in the given situation. An inappropriate way of implementing a change can degrade all previous phases and activities and make any change unsuccessful. Every change, even the smallest one, causes consequences on employees and their mutual relations: every change affects individuals, changes the order of things, positions, relationships and interactions.

The process of organizational change for its result must have a balance between the driving forces and the forces of resistance. The driving forces are pulling towards change, and the resistance forces are holding back the changes and maintaining the existing state. If resistance forces are dominant they can prevent change. The main goal of the changes is to eliminate or weaken the forces of resistance, and only then will the activities of the driving forces in the organization be strengthened. The process of organizational change is realized through the following phases:

- preparation for changes;

- changing from old to new;

- stabilization of the new situation.
Preparation for change includes a set of activities that are essentially accepting the necessary changes. This means that individuals, groups and organizations recognize and accept the necessity of change. This is the phase of overcoming resistance to change and abandoning existing ideas, habits and methods of work. The process of getting rid of the existing one is harder and longer than adopting new habits, so the help of a manager is needed.

Changing means a change of state and can only start when the defrost phase is completely completed. It means accepting and adopting new attitudes and values.

It represents the new behavior of employees in relation to the structure, processes, culture and can be done with the help of the change team.

Stabilizing a new situation means that the organization accepts and adopts a new situation with new behavior, norms, rules and procedures. This phase enables the company to function on new foundations and with new goals.

The process of organizational change includes the following activities:

- identifying and defining functioning problems;

- identifying the need for change; 
- accepting the decision on changes;

- generating ideas for implementing changes;

- creativity and innovation;

- designing and directly implementing changes.

Changes in the organizational structures of logistics companies represent dominant changes in the company and include changes in the whole and parts. Changes in the structure are a consequence of the growth and development of the company, as well as organizational factors. During the changes, new forms of organizational structures and new types of organizations are established. Previously dominant control is replaced by communication. Small units formed to perform tasks and processes are formed, organizations based on processes instead of functions. They appear as "ad hoc" structures, as a common feature for all types of flexible organizations. In modern business conditions, computer support has become indispensable, especially in process monitoring, timeliness and accuracy. New technology requires new skills and knowledge from employees. It allows you to get rid of routine tasks, leaving room for creative activities.

Employee change includes changes in the values, skills and attitudes of employees and norms of behavior of employees and managers, as individuals and within the group. In the process of change, employees in logistics organizations must learn how to use new technologies and knowledge or how to work effectively in teams. Motivation is an important factor in change. At the core of organizational changes related to employees, there are two approaches: one refers to the process of education, training and coaching of existing employees, and the other to the admission of new employees.
By their scope, organizational changes can be partial and radical. According to the level of coverage, you can include groups, teams, departments, plants or the company as a whole, or micro and macro level. In the conditions of a pandemic caused by the COVID-19 virus, organizations adapt to the external and internal environment with gradual and partial changes. Partial organizational measures solve minor crises and business delays. Gradual changes represent first-order changes. They are mild and shallow. They make improvements and partial changes in the organizational structure, technological processes, business processes and employees. Radical changes are essential and profound, they create a new structure and break the continuity of the existing organization. Radical changes change the concept and strategy of the organization. Radical changes are carried out in times of crisis when the organization is surprised by the situation.

\section{Resistance to organizational change}

The constant occurrence of all changes is the resistance of employees in the implementation of changes. Implementing major organizational changes causes stress for employees and thus leads to resistance to implementing change. The situation after the introduction of changes in the company is characterized by the fact that it is unstable and causes a feeling of insecurity in the company. The problems that companies face when approaching any major organizational change are:

- resistance to all changes because they represent something unknown,

- fear of losing personal position, power and influence,

- attitude and opinion that the existing way of working is better and that it should not be changed. 
Certainly the greatest resistance is caused by changes that affect people. For these reasons, gaining the attitude of employees that change is one of the most important tasks of management in the overall business of managing organizational change. Obstacles to implementing organizational change are:

- organizational - focus on the costs of implementing changes, the degree of risk, lack of coordination, incompetence of the system and the like.

- personal - which refer to the insecurity and fear of employees from change.

The main sources of resistance to change are:

- insecurity due to possible social losses;

- new climate and new social relations in the company;

- economic losses and damages to those individuals who lost their jobs due to changes or were transferred to a less attractive or paid job;

- ignorance and unwillingness to work on oneself, as a consequence of the requirement for additional knowledge, training and learning;

- loss of control - when the change is implemented, employees will not have control over some jobs and resources of the company that they had until then;

- unpredictable consequences - they refer to those parts of the organization and employees that are not directly but indirectly exposed to the consequences of change.

In order to eliminate these risks from changes, it is important for employees to participate in decision-making about changes. Only with the participation of employees, organizational changes without which the future functioning of the company is impossible, will have the support of the majority of employees. This means that the manager who implements the changes must consult employees and associates about them. Building the trust that managers and executives enjoy with associates is a significant factor in supporting change.

Resistance to change is overcome in several phases, these are:

- equalization with the needs and goals of users,

- communication and education,

- participation and involvement of employees,

- coercion and coercion.

People accept change in three ways:

- declarative consent in which there is no belief of the individual in the correctness of the decision on future change. identification, when there is the consent of the employees for the change, it is believed that the change is useful and that the manager is in charge.

- internal satisfaction due to the changes made, when the individual accepts the decision because it is in accordance with his approach.

The implementation of organizational changes in the company consists of several phases which are shown in the following figure (Figure 2):

Every significant organizational change in the company faces three basic problems and obstacles: - Resistance from employees affected by this change. This problem is solved by motivation.

- Difficult organizational control. It is addressed in the change management process. Control and supervision must be present at all times. 
- Loss of power, power and influence, which is solved by the policy of dynamics and implementation of changes, so that the "centers of power" support change.

The problem with the introduction of changes also comes from those who initiate the changes (owners) because most people formally want the changes but Figure 2. Phases of organizational change essentially do not want them. One fact is quite certain: it is impossible to implement changes without everyone being satisfied. It is necessary to explain to people what each of them gets from the changes in the company and to explain what the changes mean for their lives and for the organization as a whole.
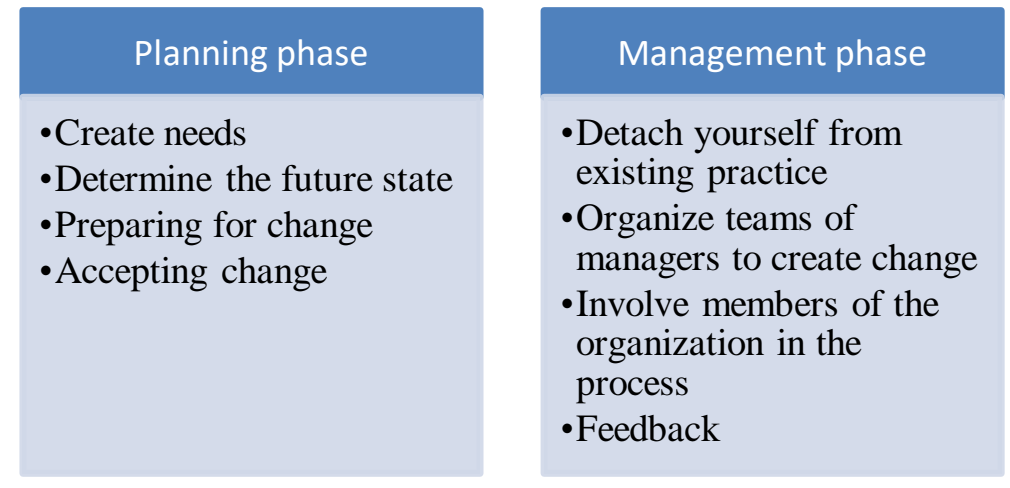

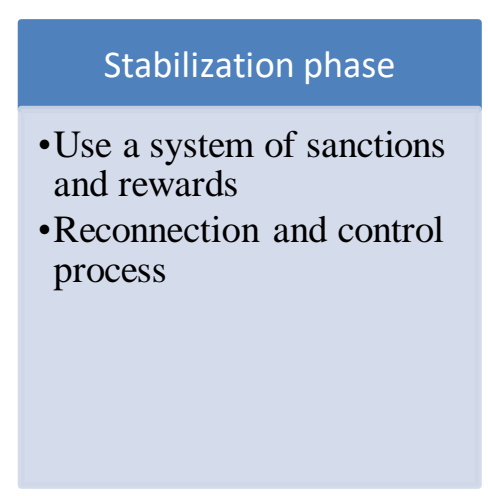

Systematized experience related to change management can help both organizational change managers and those affected by change. Here are some useful recommendations for successful implementation of organizational change:

- It takes a certain period of time for people to adapt to the changes.

- Help people know that their reactions and emotions to changes are completely normal.

- The change process must be controlled and managed.

- The time gap between the changes made and the reaction to the changes must be optimal. Every individual, more or less resists change because it introduces a certain amount of uncertainty, conflict and risk, and in order for change to be successfully implemented, it is necessary to implement strategies to overcome resistance to change.

Every organization must change both continuously and discontinuously. It goes through daily, partial changes but, often, their shape and intensity are not enough to keep up with the environment. This creates a gap between the organization and the environment, which causes a decline in performance and a crisis that encourages discontinuous changes: comprehensive, radical and intense. The choice between continuous and discontinuous changes is influenced by the dimension of uncertainty avoidance.

\section{Conclusion}

Inadequate introduction of new values into the organizational structure of logistics companies in conditions when the COVID19 infection is not yet under full control, and change management in organizational systems, can lead to contradictions in organizational and individual management of organizational change, conflict and resistance, and thus to their slow development and even failure and decline. 
National attitude and responsibility, and even health culture, has a strong influence on the organizational component of companies engaged in logistics operations, so it can be a constraint on organizational success. Interest in understanding national health security and organizational culture is growing due to globalization, enhanced international cooperation and integration and the entry of multinational companies, strengthening interdependence among nations and the expressed need to achieve market competitiveness. It is very important to understand the impact of national culture on the health of the nation and on organizational changes, types and processes of organizational change in logistics companies, in order to act responsibly in times of crisis and ensure coordinated action and homogeneous behavior of all stakeholders.

An organizational culture that is rooted in each organization can help in the process of adjusting and changing the organizational structure and that causes stress for the members of the organization. Changes in the organization ensure its compatibility with the requirements of the environment. The organizational structure and its changes are not an end in themselves, but a means of adapting to the new conditions of the external or internal environment. Change management is a new concept in modern management that respects the fact that rapid change is a specific sign of the times in which we live and that the company can not operate efficiently and develop if it does not keep pace with change and if it does not use them. The basis of successful company management is quick reaction to changes and adaptation to changes. The concept of change management becomes a management concept, which is used in the world and requires employees in the organization to acquire new knowledge, acquire new skills and abilities needed to function in new conditions, correct certain attitudes, change their work habits, values and attitudes. It also includes changes in organizational culture - changes in values, established customs, information relations, influence, changes in management style. As it is a whole process of radical change it does not take place by itself: it takes learning, and time, effort, perseverance, ability, loyalty and dedication to the work that is being done. Organizational changes of logistics companies can be made in a timely and evolutionary way, when it comes to adapting to the requirements of the environment (possibility of improving functioning, danger of competition), and revolutionary when it is too late and when the situation is bad for the organization.

\section{References}

Aničić, J., \& Aničić, D. [2019]. Which model of economic development is the best for Serbia. Journal of Process Management. New Technologies, 7(4), 46-56.

Alhasheedi, A. A. A., Bin, B. B., \& Mustafa, A. M. [2020]. The effect of transformational leadership behavior on organizational performance in gold industry of Saudi Arabia. Journal of Process Management. New Technologies , 8(3), 62-81.

Midžić, A. [2014]. Logistika,, Bihać, prema: Ballou R.H., Business Logistics Management, Prenticehall international, Inc., Upper Saddle River, 5-20.

Stošić-Mihajlović, L., \& Trajković, S. [2017]. Logistics support as efficient business and transport. Journal of Process Management. New Technologies , 5(1), 30-36.

Stošić-Mihajlović, L., \& Trajković, S. [2020]. The importance of logistics and supply chains for pandemia conditions. Journal of Process Management. New Technologies , 8(2), 53-59. 